\title{
Dominant black in horses
}

\author{
DP Sponenberg*, MC Weise \\ Department of Biosciences and Pathobiology, \\ Virginia-Maryland Regional College of Veterinary Medicine, \\ Virginia Tech, Blacksburg, VA 24061; \\ 2714 Wocjik Ln, Sobieski, WI 54171, USA
}

(Received 20 January 1997; accepted 7 March 1997)

\begin{abstract}
Summary - The existence of dominant black in horses is supported by a black stallion producing 12 black or near black and no other color of foals from bay mares, and 16 black or nearly black and no other color of foals from chestnut mares. This allele is suggested as being dominant black, $E^{D}$, at the Extension locus. This allele does not always cause completely eumelanic phenotypes, since some offspring (which were heterozygous) were near black rather than completely black. The dam of this stallion was of a near black or brown, rather than black, phenotype. The sire of this stallion was black. Foals were sometimes born a color close to that of bay foals, but these ultimately turned completely or nearly black at maturity.
\end{abstract}

color inheritance / Extension locus / dominant black / horse

Résumé - Noir dominant chez les chevaux. L'existence d'une coloration noire dominante chez les chevaux est mise en évidence par un étalon noir produisant 12 poulains de couleur noire ou presque à partir de juments bai et 16 poulains de couleur noire ou presque noire à partir de juments alezan. Cet allèle est suggéré être le noir dominant, $E^{D}$, au locus Extension. Cet allèle ne cause pas toujours des phénotypes eumélaniques puisque certains descendants (qui étaient hétérozygotes) étaient presque noirs plutôt que complètement noirs. La mère de cet étalon était presque noire ou brune, plutôt que noire. Le père de cet étalon était noir. Les poulains naissaient quelquefois avec une couleur proche de celle des poulains bai mais devenaient complètement ou presque noirs à la maturité.

hérédité de la couleur / locus Extension / noir dominant / chevaux

\section{INTRODUCTION}

The inheritance of color in horses has been studied for much of this century. Early studies were largely based on studbook data, and the accuracy of subtle distinctions in color nomenclature were sometimes lacking (Gremmel 1939, Castle 1940a, b,

\footnotetext{
* Correspondence and reprints: Veterinary College, Virginia Tech, Blackburg, VA 24061 USA
} 
1951a, b, 1954). This is especially so when horses are registered as foals, since foal coats and adult coats can be very distinct from one another. Later studies were mostly based on segregation data from selected families of horses, and provided a sound basis for the testing of hypotheses concerning the inheritance of horse color. These studies also tended to use the principles of homology in assigning loci and alleles for the various genetic phenomena controlling color (Odriozola, 1951; Adalsteinsson, 1974, 1976).

Black horses are usually considered to be uniformly covered with black hairs, and in many breeds the presence of even a few reddish or tan hairs (usually in flanks or muzzle) results in the designation of such horses as brown, or even bay, rather than black (Sponenberg, 1996). Horses with reddish brown bodies and black lower legs, manes and tails, are consistently designated as bay in most breed registries. While such red horses are consistently referred to as bay, the term bay can also include darker colors, some of which approach black. Horses with a mixture of black and reddish brown body hairs and black lower legs, manes and tails are variably considered brown or bay, depending on the breed or the observer. The brown classification can therefore include horses that are nearly black, as well as those that are nearly bay. An additional type of brown is seal brown, which has black lower legs, mane and tail, and a black body with conspicuous lighter hairs on the muzzle, over or around the eye sockets, and in the flanks and axillary regions. The genetic differences between these various sorts of brown have never been elucidated, largely because the nomenclature in the English language is ambiguous enough that it is difficult to accurately designate horses into one color group or the other (Sponenberg, 1996).

Few studies have been accomplished that finely split the various browns accurately. Abeles (1979) presents an hypothesis for the interrelationships of horses with black lower legs, manes and tails, and bodies of reddish brown, mixed reddish brown and black, or uniform black. Although no segregation data are presented, her experience is consistent with the reddish brown and black mixtures (which she refers to as brown) dominating the clear reddish browns (her bay), which in turn dominate the uniformly black bodies (her black). This is perhaps explained by the interaction of the Agouti and Extension loci. These loci have long been postulated as important in controlling common horse colors, although the hypotheses concerning their interactions have varied over the years (Odriozola, 1951; Jones, 1982; Sponenberg, 1996).

The existence of a uniform black in horses that is recessive to bay has long been acknowledged, and accounts for the majority of black horses. This black is assigned to the Agouti locus in keeping with principles of homology (Wilson, 1910; Wright, 1917; Adalsteinsson, 1976; Lauvergne et al, 1991).

The existence of a dominant black in horses has also long been speculated (Gremmel, 1939; Castle, 1940a, b, 1951a, b, 1954). The evidence for a dominant mechanism producing black has been the production of bay or brown foals from the mating of two black parents. Such instances have usually been from studbook data, which are suspect owing to the possibility of inaccuracies in the registrations of animals, or in mistakes of parentage. Another problem with studbook data for the colors bay, brown and black is one of definition. Various breeders may have different mental images of these three and consequently studbook records are 
probably inaccurate at this level of detail. Dreux (1966) presents evidence for the existence of a dominant gene contributing to black or dark bay phenotypes in the French Trotter breed, and mentions that this is rare in horses of European breeding, having been introduced through an imported American Trotter stallion.

Currently, documentation best fits with the view that the Agouti locus comprises two alleles, with bay dominant to black (Sponenberg, 1996). A third allele, black and $\tan \left(A^{t}\right)$ is fairly poorly documented as a cause of seal brown, and is intermediate in dominance to the other two alleles. The Extension locus likewise has two well-documented alleles, wild type dominant to chestnut (Sponenberg, 1996). The recessive chestnut allele, when homozygous, results in a uniformly reddish brown phenotype (including lower legs, mane and tail), and is epistatic to the Agouti locus. Past literature has postulated intricate relationships with these two loci, with no clear epistasis of one over the other, and with these intricate interactions explaining the differences between bay and brown, and between shades of chestnut (Jones, 1982). The Extension locus may well be the site of an allele that provides for the intermixture of black hairs into the red body coat of some bay horses, which translates into the difference between bay and brown. This is consistent with Abeles (1979), even though segregation data are lacking in that report.

This report discusses data that support the existence of an additional Extension allele, for dominant black, in the horse.

\section{MATERIALS AND METHODS}

Production data from a black Arabian stallion (Serr Ebony Star) were evaluated for foal color production with various colors of dams. The production data from the black sire (Shilosmidnight) and the dark brown dam (PRF Gali Gaeraff) of this stallion were similarly evaluated.

\section{RESULTS}

Results are summarized in table I. The black stallion was mated to mares of various colors. Following mating to bay mares he produced seven black and five 'near black' foals ('near black' is used to describe horses that are black save for a few tan or red hairs in muzzle or flank, or those horses that are very dark but for which it is possible to discern a subtle difference in the color of body and the lower legs, mane and tail). Following mating to black mares he produced nine black foals. Following mating to chestnut mares he produced ten black and six 'near black' foals.

The sire of this stallion was black and was mated to black mares to produce two black foals. Matings to bay mares resulted in three black and three bay foals. Matings to chestnut mares resulted in one black and two bay foals.

The dam of this stallion was dark brown, and was mated to a black stallion to produce one black foal and three 'near black' foals. A mating to a chestnut stallion produced a 'near black' foal. 
Table I. Production results of mating black horses to mates of various colors.

\begin{tabular}{|c|c|c|c|c|}
\hline \multirow[t]{2}{*}{ Horse } & \multirow[t]{2}{*}{ Mate color } & \multicolumn{3}{|c|}{ Foal color } \\
\hline & & Black & Near black & Bay \\
\hline \multirow[t]{3}{*}{ Stallion } & black & 9 & 0 & 0 \\
\hline & bay & 7 & 5 & 0 \\
\hline & chestnut & 10 & 6 & 0 \\
\hline \multirow[t]{3}{*}{ Sire } & black & 2 & 0 & 0 \\
\hline & bay & 3 & 0 & 3 \\
\hline & chestnut & 1 & 0 & 2 \\
\hline \multirow[t]{2}{*}{ Dam } & black & 1 & 3 & 0 \\
\hline & chestnut & 0 & 1 & 0 \\
\hline
\end{tabular}

\section{DISCUSSION}

The problem of nomenclature concerning dark horses is a concern for this study. In the Arabian breed many breeders are very strict in their use of the term black, and reserve it for horses with black hairs only, excepting white marks due to spotting patterns. Arabian breeders do not use the term brown, and so horses that are nearly but not quite black are usually referred to as black bays, or even simply as bay. These are, however, very distinct from the usual bright reddish brown bay that is typical in the breed. Black bays in the Arabian breed are easy to confuse with black horses, especially without close and detailed examination, and are difficult to confuse with bright reddish brown bay horses, which are common in this breed. The grouping of blacks and near blacks, or black bays, as one group is therefore logical, since this is how these colors appear to most observers. These three are very close to one another visually, if not in terms of nomenclature.

The results of the mating of the horses of this study is consistent with the segregation of a dominant allele for black. The mating of the stallion to bay mares for 12 foals can be tested for goodness of fit for the hypothesis that this stallion is a recessive black. If that were the case, and if all the bay mares were heterozygous for this usually rare allele, then $X^{2}=12,1 \mathrm{df}, P<0.005$. This deviates significantly from the expectation, even postulating the most favorable condition of all the bay mares being heterozygous for a rare allele. These results are therefore inconsistent with the segregation of a recessive allele for black, but are consistent with the stallion being homozygous for a dominant allele causing black color.

The sire of this stallion was black, while the dam was dark brown. Both needed to have had the allele causing dominant black if the stallion is indeed homozygous, as is supported by the segregation data. The mare always produced black or near black foals when mated to a black stallion. She also produced a near black foal when mated to a chestnut stallion, even though she is an obligate heterozygote for dominant black by virtue of having had a bay sire. The sire of the stallion produced equal numbers of bay and black foals when mated to bay mares, which is further 
evidence that a dominant gene is segregating in this family of horses. The sire of the stallion is heterozygous for this gene, even though both of his parents were black.

A few of the foals in this study were born a color resembling that of foals that ultimately prove to be bay. These foals darkened with age, ultimately becoming black or nearly so. Some of the blackest of the horses in this study were born with this light bay foal coat, only to darken later. It is fairly typical for black horses (assumed to be of the recessive Agouti genotype) to be born an ashy grey color, to darken later. Whether or not the differences in foal coat are consistent with these two different genetic mechanisms that cause black horses is undetermined.

The allele causing the black phenotype in these horses is most likely the dominant black $\left(E^{D}\right)$ at the Extension locus. This allele is documented in numerous other species as a cause of uniformly eumelanic phenotypes (Searle, 1968). It appears to be arguably incomplete in its action in some instances, causing dark brown or near black instead of truly black individuals. In foxes, for example, the $E^{D}$ allele is frequently incompletely dominant resulting in three color classes from this allele and the wild type allele (Adalsteinsson et al, 1987). The dominant black allele may be the genetic mechanism behind some of the very dark phenotypes in horses that are not truly uniformly black. The differences in genotype between the black and nearly black horses are uncertain, since in this data set it is conservative to assume that most, if not all, of these had the Agouti locus bay allele, and its presence or absence can therefore not be responsible for the subtle differences in the black and near black horses. Likewise, most of these foals had to have been heterozygous for the dominant black allele, and this genotype includes both black and near black individuals. The dominant black allele appears to be rare in most breeds, since in most breeds black does segregate as a recessive.

\section{REFERENCES}

Abeles HM-S (1979) A coat of many colors. Equus 17, 30-38

Adalsteinsson S (1974) Inheritance of the palomino color in Icelandic horses. J. Hered. 65, 15-20

Adalsteinsson S (1976) Colour inheritance in Icelandic Ponies. In: First Int. Symp. on Genet. and Horse Breed., Royal Dublin Soc. Dublin, 17-18 September 1975, 42-49

Adalsteinsson S, Hersteinsson P, Gunnarsson E (1987) Fox colors in relation to colors in mice and sheep. J. Hered. $78,235-237$

Castle W (1940a) Mammalian Genetics. Harvard University Press, Cambridge, Massachusetts

Castle W (1940b) The genetics of coat color in horses. J. Hered. 31, 127-28

Castle W (1951a) Dominant and recessive black in mammals. J. Hered. 42, 48-50

Castle W (1951b) Genetics of the color variety of horses. J. Hered. 42, 297

Castle W (1954) Coat colour inheritance in horses and in other animals. Genetics 39, 35-44

Dreux P (1966) Contribution à l'étude du gène $\mathrm{E}$ chez le cheval domestique. Ann Génét, $9,168-170$

Gremmel F (1939) Coat colors in horses. J. Hered. 30, 437-45

Jones WE (1982) Genetics and Horse Breeding. Lee and Febiger Publishers, Philadelphia

Lauvergne JJ, Silvestrelli M, Langlois B, Renieri D, Poirel D, Antaldi GGV (1991) A new scheme for describing horse coat colour. Livest. Prod. Sci. 27, 219-229 
Odriozola M (1951) A los colores del caballo. Publicaciones del Sindicato Nacional de Ganadería, Madrid

Searle A (1968) Comparative Genetics of Coat Colour in Mammals. Logos, London Sponenberg DP (1996) Equine Color Genetics. Iowa State University Press, Ames, Iowa Wilson J (1910) The inheritance of coat colour in horses. Proc. Royal Dublin Soc. 12, 341-348

Wright S (1917) Color inheritance in mammals VII: The horse. J. Hered. 8, 560-64. 